\title{
Aporias criminológicas: "Coringa" e a desconstrução do binário herói/vilão
}

\author{
Recebido: 22 de maio de 2020 • Aprovado: 30 de junho de 2020 \\ https://doi.org/10.22395/ojum.v20n4la12
}

\author{
Bruno Amaral Machado \\ Centro Universitário de Brasília (UniCEUB), Brasília, Brasil \\ brunoamachado@hotmail.com \\ https://orcid.org/0000-0002-7425-7066 \\ Lucas Villa \\ Universidade Federal do Piauí (UFPI), Teresina, Brasil \\ lucasvilla@ufpi.edu.br \\ https://orcid.org/0000-0003-1771-7107
}

\section{RESUMO}

O artigo propõe análise criminológica e filosófica do filme "Coringa", de Todd Phillips. A partir da categoria memória social, sob a lente da desconstrução, pretendemos (re) imaginar o binário herói/vilão que estrutura a narrativa fílmica hollywoodiana. Nesse ponto, propomos repensar o binário verdadeiro/falso para descrever e desafiar as imagens estabilizadas sobre os enunciados da ciência. Sugerimos que as narrativas em torno da cidade mítica, povoada por heróis e vilões, conformam parte da memória social desse gênero peculiar na história do cinema. O cenário descrito é reelaborado a partir das semânticas criminológicas que articulamos ("criminologias de médicos, advogados e sociólogos") no debate com o leitor. Na última parte, pelas mãos de Jacques Derrida, propomos lente filosófica pós-metafísica da narrativa fílmica. A partir da desconstrução do binário herói/vilão investimos nas brechas que levam à desconstrução do binário verdadeiro/falso, estabilizado no discurso científico, e do binário criminológico etiologia/reação social. Ao final, sugerimos que a proposta fílmica do Coringa se constitui em paradigma para se pensar as criminologias "do" cinema.

Palavras-chave: cinema; memória social; semânticas criminológicas; verdade; desconstrução. 


\section{Criminological Aporias: "Joker" and the Desconstruction of the Hero/Villain Binary}

\section{ABSTRACT}

This article proposes a criminological and philosophical analysis of the film "Joker", by Todd Phillips. From the category of social memory, under the lens of deconstruction, we intend to (re) imagine the hero/villain binary that structures the hollywoodian film narrative. We propose a rethinking of the true/false binary to describe and challenge the stabilized images about the statements of science. Our writing starts from what we call Gotham City mythology, where we describe the archetypes and legends that populate the city immortalized in the comics and films. By situating the place where the scene takes place, we expose the work's plot and situate the characters and their trajectories. We suggest that the narratives around the mythical city, populated by heroes and villains, make up part of the social memory of this peculiar genre in the history of cinema. And they accumulate valuable material from which we use different discourses to think and describe concrete problems such as conflicts, violence and crusades against deviation. The scenario described is reworked based on the criminological semantics we articulate ("criminologies of doctors, lawyers and sociologists") in the debate with the reader. In the last part, with the assistance Jacques Derrida, we propose a post-metaphysical philosophical lens of the film narrative. From the deconstruction of the hero/villain binary, we invest in the loopholes that lead to the deconstruction of the true/false binary, stabilized in scientific discourse, and the criminological etiology/social reaction binary. In the end, we suggest that the Joker film proposal constitutes a paradigm for thinking about the criminologies of "cinema".

Keywords: cinema; social memory; criminological semanthics; truth; desconstruction. 


\section{Aporías criminológicas: "Guasón" y la desconstrucción del binario héroe y villano}

\section{RESUMEN}

El artículo propone un análisis criminológico y filosófico de la película "Guasón" (Joker), de Todd Phillips. A partir de la categoría memoria social en el marco de la desconstrucción, deseamos (re) pensar el par héroe/ villano que estructura la narrativa cinematográfica hollywoodiana. En este punto, proponemos repensar el binario verdadero/ falso para describir y cuestionar las imágenes estables sobre los enunciados de la ciencia. Recomendamos que los relatos en torno de a la ciudad mítica, poblada por héroes y villanos, hace parte de la memoria social de este género peculiar en la historia del cine. El escenario descrito se reelabora a partir de las semánticas criminológicas que articulan ("criminologías de médicos, abogados y sociólogos") en el debate con el lector. En la última parte, por las manos de Jacques Derrida, proponemos mirada filosófica post-metafísica de la trama cinematográfica. Comenzando de la desconstrucción del binario héroe/ villano enfocamos en los puntos que llevan a la desconstrucción del binario verdadero/ falso, estable en el discurso científico, y del binario criminológico etiología/ reacción social. Al final, recomendamos que la propuesta de la película "Guasón" constituyese como un paradigma para pensar las criminologías cinematográficas.

Palabras clave: cine; memoria social; semánticas criminológicas; verdad; desconstrucción. 


\section{INTRODUÇÃOO}

As interseções entre o Cinema e a Criminologia abriram campo de debate, ainda em construção, nos últimos anos. Este artigo integra a linha de pesquisa Criminologia e Arte do Grupo de Pesquisa Política Criminal (Uniceub/Unb) e procura explorar as múltiplas interseções entre os pensamentos criminológicos e a produção fílmica. Como sugerimos em recente estudo, as negociações sobre os sentidos da conflitualidade, da violência e do desvio no Cinema sugerem horizonte rico para a pesquisa criminológica contemporânea. As imagens e narrativas sobre o desvio e o crime constituem manifestações de criminologias populares que interpelam os saberes acadêmicos. Ao desafiar as tradições historicamente descritas como criminologias científicas, propõem novas possibilidades de observação e de descrição (Machado e Zackseski, 2019, p. 288).

As tradições criminológicas acumularam, desde o século XIX, inventário extenso de explicações para o crime, o desvio e suas formas de controle. Não se tratam de paradigmas sucessivos, mas concorrentes, pois os acúmulos podem ser localizados em distintas correntes, contemporâneas e contrapostas. As constantes atualizações dos discursos apontam para um campo complexo e em constante transformação. Os discursos acadêmicos configuram semânticas criminológicas distintas, constituindo memória social sobre o crime, o desviado e as formas de controle. Uma breve história da disciplina indica a atualidade dos discursos biocriminológicos, focados na associação entre corpo e agressividade. As correntes sociológicas, de variadas bases epistemológicas, percorrem tanto a via etiológica quanto os caminhos do interacionismo (modelos sequenciais e da reação social, por exemplo) e das vertentes críticas, com agendas e foco diferenciados.

O cinema pode servir como espaço para a reflexão crítica sobre temas que ocupam a agenda criminológica, na medida em que o espectador é desafiado a repensar visões consolidadas sobre as violências, os controles sociais formais e informais, as respostas institucionais e o castigo estatal. E pode interpelar discursos criminológicos críticos e contemplar agendas comuns, momento em que a narrativa artística se aproxima de parte dos discursos acadêmicos. Mas a produção cinematográfica também pode se constituir em locus de difusão de preconceitos, do racismo, da misoginia e do discurso do ódio. As narrativas não raramente são ambíguas ou se abrem a diferentes vias. Há agenda extensa a ser explorada.

Neste estudo propomos análise criminológica e filosófica do filme "Coringa", de Todd Phillips. A partir da categoria memória social na tradição sistêmica, revisitada pela desconstrução, pretendemos (re) imaginar o binário herói/vilão que estrutura a narrativa fílmica hollywoodiana e, assim, repensar o binário verdadeiro/falso para descrever e desafiar as imagens estabilizadas sobre os enunciados da ciência. Nossa escrita parte do que denominamos de mitologia de Gotham City, momento em que descrevemos os arquétipos e lendas que povoam a cidade imortalizada nos comics e filmes. Ao apresentar o local em que transcorre a cena, expomos o enredo da obra e 
situamos os personagens e suas trajetórias. Sugerimos que as narrativas em torno da cidade mítica, povoada por heróis e vilões, conformam parte da memória social desse gênero peculiar na história do cinema. Essas narrativas acumulam material valioso a partir do qual acionamos distintos discursos para pensar e descrever problemas concretos como os conflitos, as violências e as cruzadas contra o desvio. O cenário descrito é reelaborado a partir das semânticas criminológicas que articulamos ("criminologias de médicos, advogados e sociólogos") no debate com o leitor. Na última parte, pelas mãos de Jacques Derrida, propomos lente filosófica pós-metafísica da narrativa fílmica. A partir da desconstrução do binário herói/vilão investimos nas brechas que levam à desconstrução do binário verdadeiro/falso, estabilizado no discurso científico, e do binário criminológico etiologia/reação social. Ao final sugerimos que a proposta fílmica do "Coringa" constitui paradigma para se pensar as criminologias "do" cinema.

Algumas questões metodológicas e opções teóricas devem ser esclarecidas. A narrativa evidencia repertório aberto a múltiplas possibilidades teóricas e interlocuções filosóficas e criminológicas. No nosso percurso sugerimos duas vias: inicialmente, a construtivista, na vertente proposta por Luhmann, particularmente para a descrição das criminologias como subsistemas da ciência; na segunda parte, pela via desconstrucionista (Derrida), sugerimos outras possibilidades (transgressoras) de observação dos significantes estabilizados nas comunicações do cinema e das criminologias. Os repertórios abrem-se à revisitação, ao questionamento e disponibilizam novos cenários. Justificamos as escolhas: a teoria sistêmica constitui-se em ambiciosa proposta teórica para a descrição das sociedades contemporâneas. Propõe, entre outras frentes, a observação das comunicações em sistemas sociais diferenciados funcionalmente (política, economia, direito, religião, arte, ciência). Em sociedades diferenciadas funcionalmente, as comunicações vinculam-se a sistemas sociais autopoiéticos, que operam com programas e códigos próprios. No enfoque sistêmico, a função da memória social é liberar a capacidade de informação para que o sistema se abra a ressonâncias do entorno, pelo binário recordar/esquecer. A memória social não é o que as comunicações deixam como rastro nas consciências individuais, mas o resultado das próprias operações comunicativas. Toda comunicação atualiza determinado sentido (razão da memória social) (Luhmann, 2007, p. 457-458, p. 464)․ A partir do mecanismo recursivo de novas operações, o observador pode identificar as mudanças estruturais históricas. Permite-se, assim, observar diferentes semânticas sociais. Particularmente, para o nosso artigo, aquelas produzidas pela arte (cinemas) e pela ciência (criminologias).

No giro proposto pela mão de Derrida, os códigos binários e os programas (su plementos) que orientam as semânticas da arte e da ciência são colocados em xeque. A memória social dissimula ou esconde suas aporias. Se a escrita possibilita a memória

O uso repetido das mesmas referências permite inferir que assim será em casos futuros. Em síntese, se a evolução ocorre na forma variação - seleção - estabilização, a memória operativa do sistema ocupa-se de acoplar o passado ao futuro, por meio de distinções (Luhmann, 2007, p. 461-464). 
social (Luhmann, 2007), também carrega a marca ambígua do phármakon (remédio e veneno) (Derrida, 2005). Ao questionar as semânticas binárias, abrimos novos cenários, transgressores, que nos apontam para outras possibilidades hermenêuticas. Um último esclarecimento é necessário. Decidimos representar a diversidade dos pensamentos criminológicos como "criminologias de médicos e advogados" e "criminologias de sociólogos" (Zaffaroni, 2011). Por "criminologias de médicos e advogados" nos referimos às tradições biocriminológicas como matriz etiológica do comportamento desviado, às visões remanescentes do livre arbítrio (Escola Clássica) e à tradução de semânticas criminológicas (particularmente biocriminológicas) nas operações heterorreferentes do sistema jurídico. Por "criminologias de sociólogos" nos referimos às tradições no campo da sociologia criminal, que conformam repertório igualmente extenso e que contempla tanto modelos etiológicos, com explicações causais de fundo social, quanto tradições compreensivas e interpretativas, preocupadas tanto com os processos por meio dos quais os sujeitos atuam e interagem conforme sentidos compartilhados, quanto aquelas cujo foco foi redirecionado para a reação social e o etiquetamento dos comportamentos definidos como desviados.

\section{GOTHAM CITY: MITOS E ARQUÉTIPOS}

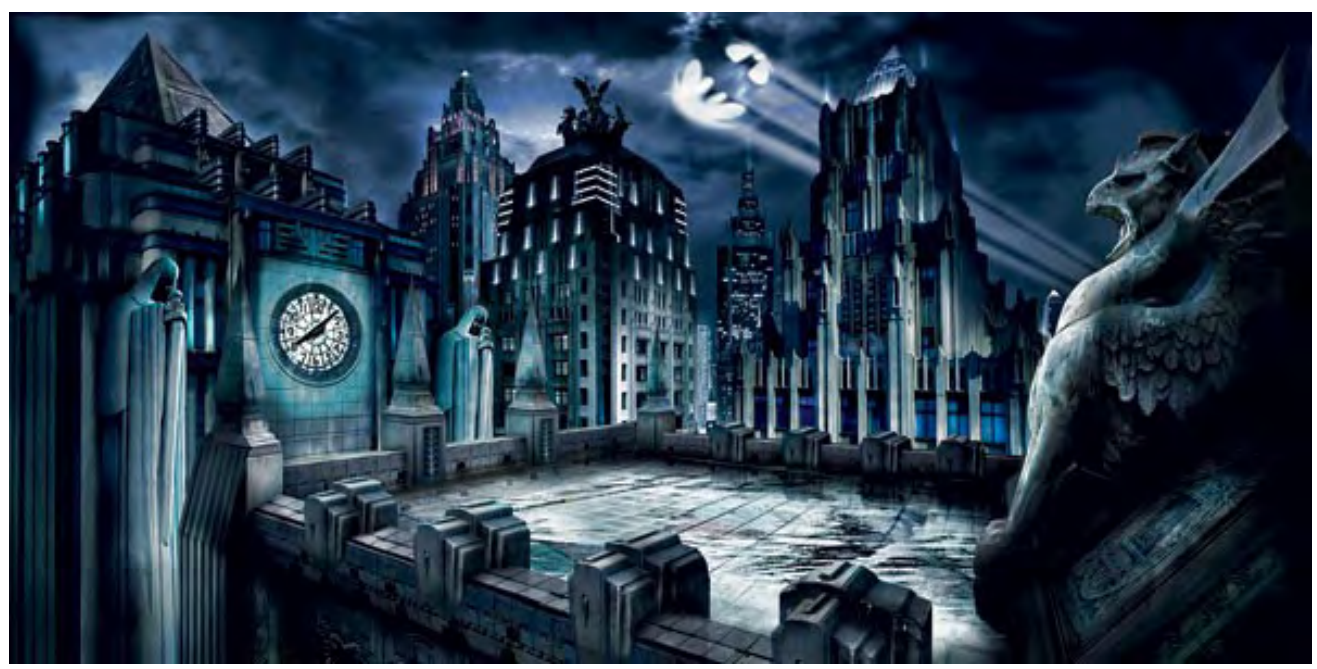

Figura 1. Gotham City.

Fonte: Mortal Kombat Fandom (s.f.)

O gênero Animated cartoons tem despertado crescente interesse acadêmico. Discutem-se os significados além da mera animação, como âmbito rico para a análise cultural (Cornelio, 2004, p. 2) 2. Na transposição para as telas do Cinema, Schatz propõe olhar os gêneros cinematográficos de Hollywood como forma peculiar de 
cooperação entre artistas e público, uma celebração de valores coletivos. Sugere uma analogia com a produção de mitos, pois propõem coerência para encarar a ordem social (Schatz, 1981, p. 15).

Estudos sobre animações e filmes inspirados por esse gênero e, particularmente, das histórias de super-heróis que ganham versões no Cinema, sugerem repertório de imagens associadas ao espaço em que transcorrem as aventuras e aos personagens: protagonistas que encarnam a virtude e o bem, contrapostos aos vilões, encarnação da destruição e do mal. Trazem, também, estereótipos, inclusive raciais, que reproduzem a luta do bem contra o mal (Chambliss e Svitavsky, 2008). O cenário faz parte do jogo de cena, pois confere sentido à trama e atua para transportar o leitor (escrita) e o espectador (cinema) para o lugar vivido pelas personagens.

Gotham City é a cidade criada para abrigar toda a plêiade de personagens que contextualizam as narrativas em torno de uma figura principal: Batman, o homemmorcego. A relação entre Batman e Gotham é indissociável ao ponto de fazer com que um seja impensável sem o outro. Cidade caótica de aparente soberania, com ares de cidade-estado grega, mas dominada pelo crime e pela corrupção, existe para abrigar o Cavaleiro das Trevas. Batman, por sua vez, existe apenas porque há crime e corrupção em Gotham. A relação é, ao mesmo tempo, simbiótica e parasitária (Urionaguena, 2016, p. 9). Os personagens que habitam Gotham desafiam as narrativas tradicionais de super-heróis, baseadas na dicotomia herói/vilão, povoada por protagonistas movidos por nobres intenções abstratas (salvar o mundo) e antagonistas obcecados pelo desejo de fazer o mal e dominar o mundo. Em regra, essas narrativas oferecem personagens planos, pouco humanos; dos heróis exaltam-se unicamente as qualidades, enquanto os vilões assim se apresentam por seus vícios e defeitos de caráter.

A "mitologia" de Gotham, com seus arquétipos e personagens esféricos, contraria esse modelo de maniqueísmo binário, a começar por sua figura principal. Batman é Bruce Wayne, herói sem superpoderes e movido por um desejo humano, demasiado humano: vingança. Ainda criança, presenciou seus pais serem assassinados por um assaltante, o que lhe causou a obsessão por lutar contra o crime e "higienizar" Gotham City. Bruce é o herdeiro único da fortuna bilionária de família de industriais. Não veio de outro planeta, não foi picado por uma aranha radioativa nem carrega um anel que lhe confere o controle sobre o mundo físico. Não voa, não é indestrutível nem se movimenta na velocidade da luz. Seus únicos poderes são a inteligência e o vil metal: com o dinheiro da Wayne Enterprises, é capaz de mandar fabricar para si o mais moderno arsenal tecnológico de guerra (cinto de utilidades, batmóvel, batcaverna...). Bruce Wayne, aliás, não é sequer um self-made-man: a fortuna usada para sua cruzada contra o crime não foi adquirida por seu mérito e esforço, mas herdada na mais tenra idade. Humano, demasiado humano(Nietzsche, 2006). Soturno, com qualidades, defeitos e seríssimos problemas psicológicos, Batman é um protagonis- 
ta que desafia o binômio herói/vilão típico dos Comics. Nas telas, já foi interpretado, por exemplo, por Adam West ("Batman" - série de TV de 1966), Michael Keaton ("Batman" e "Batman Returns", de Tim Burton), Val Kilmer ("Batman Forever", de Joel Schumacher), George Clooney ("Batman \& Robin", de Joel Schumacher), Chistian Bale ("Batman Begins", "The Dark Knight" e "The Dark Knight Rises", de Christopher Nolan), Ben Affleck ("Batman v Superman" e "Justice League", de Zack Snyder).

Ele não é, no entanto, um caso único. Gotham é povoada de figuras assim. Seus antagonistas vão de encontro ao que se espera de um super-vilão. Oswald Cobblepot, o Pinguim, é um órfão abandonado, com deficiência física ${ }^{3}$, marginalizado, humilhado e vítima de preconceito. Bondoso com os animais, especialmente com as aves, traz consigo mágoa profunda daquilo que o mundo fez consigo. Parece, ademais, ser movido pelo mesmo animus que impele o homem-morcego: vingança. Sua versão mais icônica para as telas foi a vivida por Danny DeVito, em "Batman Returns", de Tim Burton.

Harvey Dent, o Duas-Caras, era Promotor Público zeloso, preparado e comprometido com o combate ao crime, até lhe lançarem ácido à face, deformando metade de seu rosto. A vergonha de sua nova (des) configuração estética transforma rapidamente o herói em vilão, marcado por profunda dualidade entre o sentimento de justiça e o desejo de caos - dualidade que se representa pelo hábito referir-se a si mesmo na primeira pessoa do plural e de decidir o futuro de suas vítimas lançando ao ar uma moeda. Nos cinemas, celebrizou-se nas interpretações de Tommy Lee Jones, em "Batman Forever", dirigido por Joel Schumacher, e de Aaron Eckhart, em "The Dark Knight", dirigido por Christopher Nolan.

Edward Nigma, o Charada, quando criança foi vítima de bulling. Filho de pai agressivo e mãe ausente, resolve dedicar-se ao crime para exercitar a própria inteligência e provar ser digno de respeito. Quando perdeu a memória em razão de pancada na cabeça, Edward voltou as costas ao crime e passou a usar a mesma inteligência como investigador particular, chegando a se tornar aliado eventual de Batman ${ }^{4}$ o que mostra que aquele mesmo ser humano, tendo apagada a história de sua infância traumática, tomaria rumos absolutamente distintos na vida. Foi vivido no cinema, por Jim Carrey, também em "Batman Forever".

Por sua vez, Selina Kyle, a Mulher-Gato, é personagem tão ambivalente que sequer pode ser classificada como heroína ou vilã, e pode ser descrita como espécie de anti-heroína. Seu caráter dúbio é muito bem retratado no filme "Batman Returns", de Tim Burton, onde é interpretada por Michelle Pfeiffer. Em alguns momentos, aliando-se ao Pinguim, em outros ao Batman. Assim, envolve-se com o protagonista uma relação que é misto de romance e rivalidade.

3 Em algumas versões como, por exemplo, no filme Batman Returns, de Tim Burton.

4 Episódio narrado na série de HOs "Crise infinita". 
Em que pese a diversidade de antagonistas, o arqui-inimigo de Batman é o Coringa, o palhaço do crime, geralmente retratado como psicopata ardiloso, sádico e inteligente, sedento por caos. Em comum com as demais personagens que povoam a mitologia de Gotham, não tem superpoderes e é movido por desejos humanos e desordens psicológicas. Sua história, no entanto, permanecia oculta até o contundente filme de Todd Phillips, embora já tenha sido por diversas vezes encarnado no cinema. O personagem já contou com interpretações memoráveis, como a de Jack Nicholson ("Batman", de Tim Burton). Também já foi vivido por Jared Leto ("Suicide Squad", de David Ayer) e foi a única na história do cinema a vencer dois Oscars. A façanha deuse com as atuações no mínimo perturbadoras de Heath Ledger ("The Dark Knight", de Christopher Nolan) e Joaquin Phoenix ("Joker", de Todd Phillips).

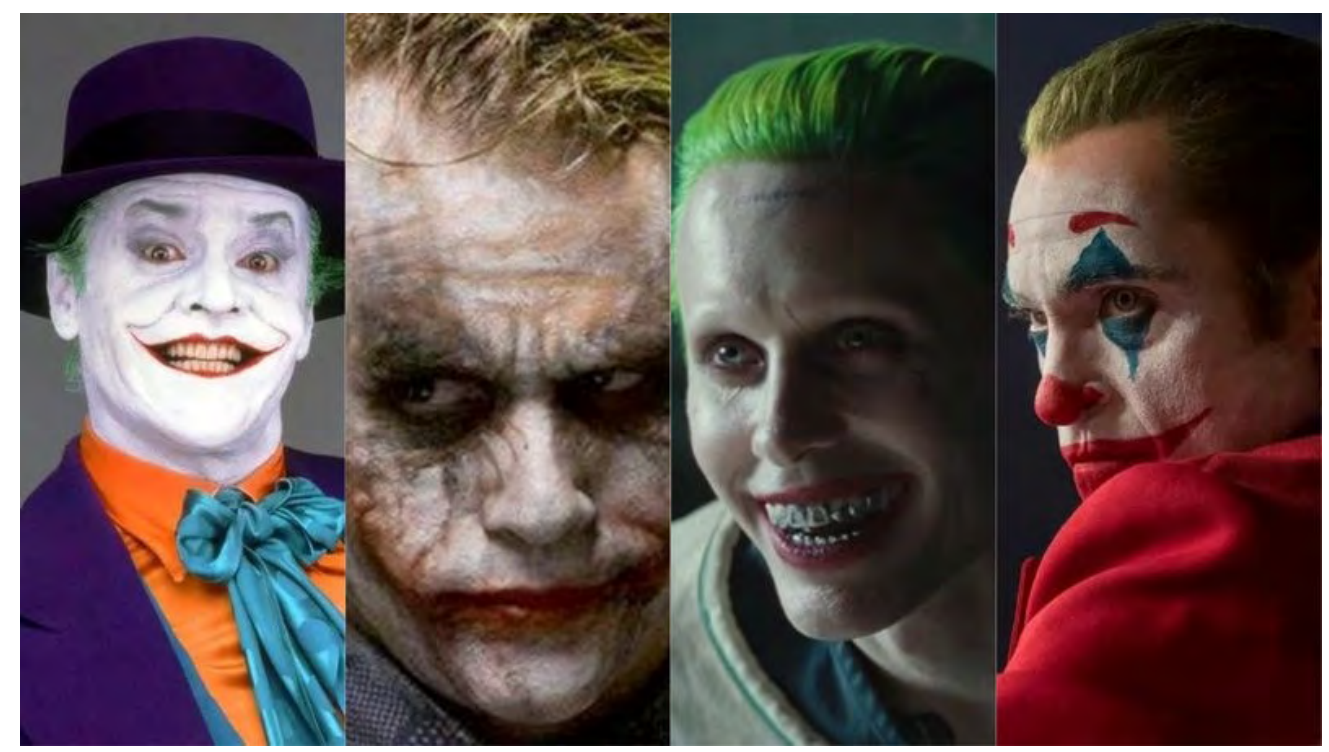

Figura 2. Atores que viveram o "Coringa" nas telas do cinema (da esquerda para a direita): Jack Nicholson, Heath Ledger, Jared Leto e Joaquin Phoenix.

Fonte: adaptação de imagens coletadas na web sobre os atores citados. 


\section{O ENREDO}

\subsection{Primeiro ato: Conhecendo Arthur Fleck}

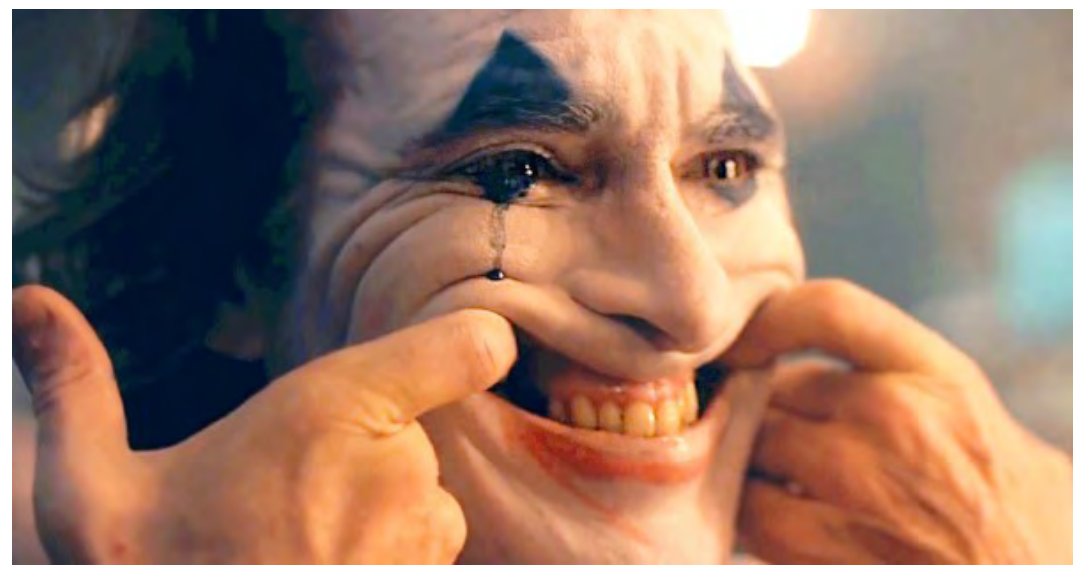

Figura 3. Atores que viveram o "Coringa”

Fonte: Phillips, T. (2019)

O filme tem como cenário uma Gotham City dos anos 1980, auge das políticas fiscais do modelo ultraliberal que ficou conhecido como Reaganomics. O cenário de terra devastada denuncia escalada da violência que parece acompanhada de profunda crise moral e de descrédito no american way of life. Confronto contra sindicatos, greve dos trabalhadores da coleta de lixo, desesperança e desemprego: este é o plano de fundo que se descortina na Gotham sombria e decadente que nos é apresentada.

Arthur Fleck, personagem principal, é um sujeito introspectivo, com problemas mentais, marcadamente surtos de riso incontido, diagnosticado como afeto pseudobulbar, que sonha em ser comediante. Mora com a mãe doente, que depende de seus cuidados, e aluga seu corpo como palhaço de rua e de hospital. No exercício de seu trabalho, do qual acabará por ser demitido, sofre agressões físicas, assédio moral e toda sorte de humilhações e degradações.

A narrativa tem início com Arthur maquiando-se como palhaço, enquanto a rádio anuncia acúmulo de lixo nas ruas. Diante do espelho, alterna expressões artificiais de tristeza e felicidade. Uma lágrima solitária escorre do olho direito e mancha a maquiagem. Em seguida, ovemos em ação, trabalhando como palhaço em frente a uma loja. "Liquidação total", dizo cartazqueele carrega enquanto dança. Adolescentes, então, passam zombando do palhaço, derrubam seu cartaz e levam-no consigo. Arthur os persegue pelas ruas de Gotham. Lixo por toda parte. Os garotos esperam-no em um beco. Quebram o cartaz em sua face e espancam-no. "Esse cara é fraco. Não é de nada". O palhaço agoniza no chão. 
O roteiro nos conduz, após, ao primeiro surto de riso incontido, desesperador para quem vê. Arthur convulsiona em misto de sorriso e choro, diante de uma assistente social pública com quem se consulta. Sabemos, então, que dessas consultas depende para continuar recebendo os sete medicamentos que toma e que deveriam evitar ou amenizar seus surtos psicóticos:

Arthur: É impressão minha ou o mundo está ficando mais louco?

Assistente Social: Está certamente mais tenso. As pessoas estão aborrecidas. Elas estão batalhando. Procurando emprego. São tempos difíceis. E você? Continua escrevendo seu diário? (Phillips, 2019).

A assistente social pede para ver o diário e a câmera nos permite entrever, pela primeira vez, uma frase nele escrita: I hope my death makes more sense cents than my life.

Assistente Social: Qual a sensação de ter que vir aqui? Ajuda ter alguém com quem conversar?

Arthur: Eu me sentia melhor quando estava preso no sanatório. Será que você pode pedir para o médico aumentar minha medicação?

Assistente Social: Arthur, você toma sete remédios diferentes. Certamente estão fazendo algum efeito.

Arthur: Eu só não quero mais me sentir tão mal (Phillips, 2019).

O espectador é conduzido a uma segunda visita à mesma assistente social. Presenciamos o primeiro apelo por empatia, seguido de uma trágica notícia. Enquanto Arthur tenta falar sobre seus sentimentos, dizendo que ninguém lhe nota e que sequer sabe se realmente existe, a assistente social lhe interrompe:

Assistente Social: - Arthur, eu tenho uma má notícia para você.

Arthur: Você não me ouve, não é? Acho que você nunca me escuta de verdade. Você faz as mesmas perguntas toda semana. "Como vai seu trabalho? Está tendo pensamentos negativos?" Só o que tenho são pensamentos negativos, mas você não me ouve mesmo. Eu disse que, durante toda a minha vida, eu nem sabia se eu realmente existia. Mas eu existo, sim. E as pessoas estão começando a perceber.

Assistente Social: Cortaram a nossa verba. Fecharemos as portas na semana que vem. A prefeitura cortou verba em todas as áreas, incluindo serviço social. É a última vez que nos encontramos. Estão se lixando para pessoas como você. E estão se lixando para pessoas como eu também.

Arthur: Merda. Como vou conseguir meus remédios agora? Com quem vou falar? Assistente Social: Eu sinto muito, Arthur (Phillips, 2019).

\footnotetext{
"Espero que minha morte faça mais sentido centavos que a minha vida".
} 
As verbas foram cortadas. Simples assim. Não haverá mais consultas e nem medicamentos. Ele está entregue à própria sorte. Ecoa a fala da assistente social: ninguém se importa. Nem com ele, nem com ela.

\subsection{Segundo ato: nasce o Coringa}

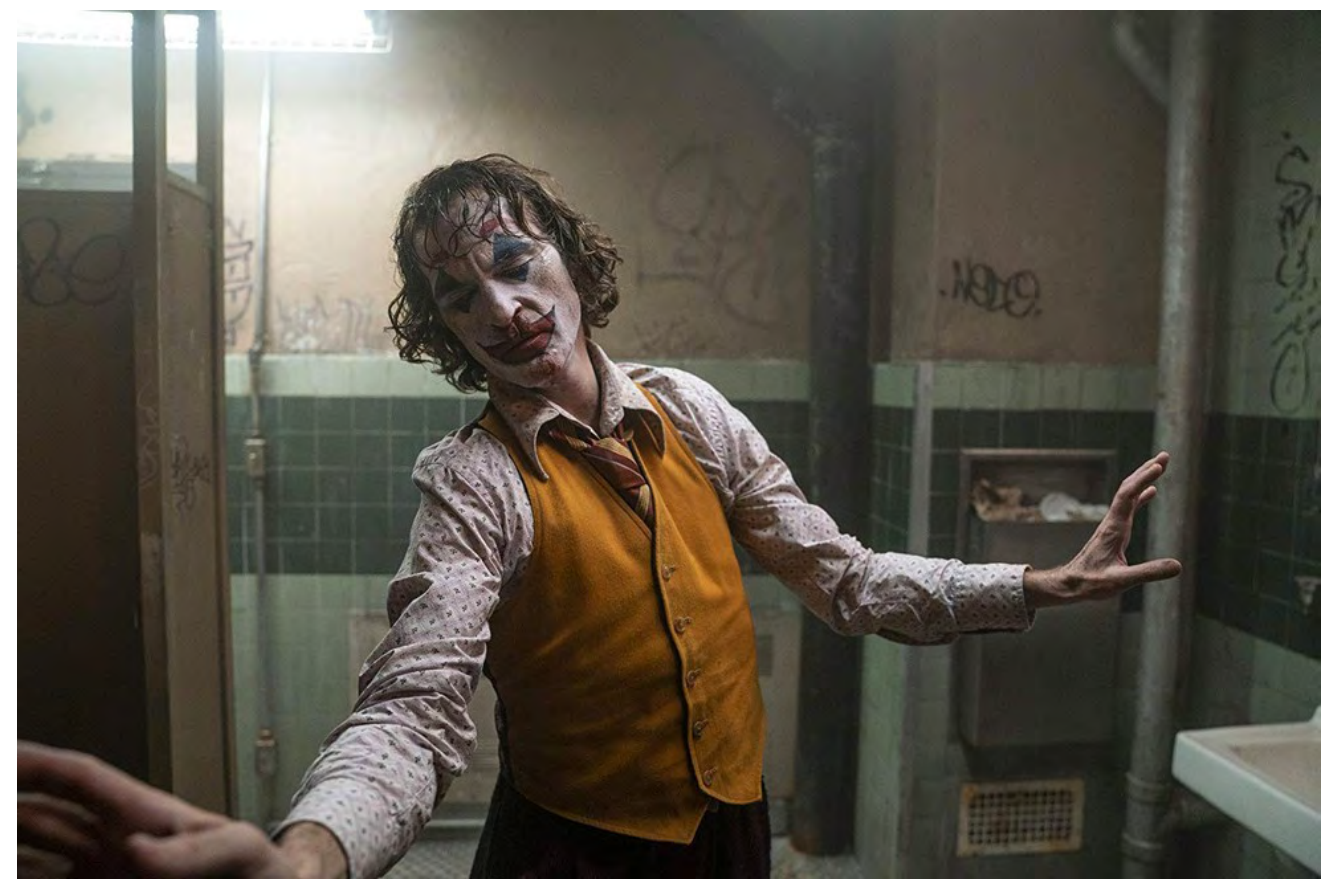

Figura 4. Atores que viveram o "Coringa".

Fonte: Phillips (2019)

O episódio do espancamento quando atuava como palhaço de rua lhe rendeu advertência no trabalho. Seu chefe, Hoyt, avisou que descontaria de seu salário o cartaz que Arthur não devolveu, pois havia sido quebrado em sua cabeça quando espancado. O diálogo explicita a imagem de Arthur perante seu chefe:

Hoyt: E a carreira na comédia? Já é famoso no stand-up?

Arthur: Eu não. Estou trabalhando nos meus textos.

Hoyt: Não se sente. Vai ser rápido. Eu gosto de você, Arthur. Muitos aqui acham você esquisito, mas eu gosto de você. Não sei porque eu gosto. Mas recebi mais uma queixa. Isso começa a me deixar puto. É da loja Kenny's. O cara disse que você sumiu. Nem devolveu o cartaz.

Arthur: Porque eu fui agredido. Você não soube? 
Hoyt: Por um cartaz? Isso é conversa. Não faz sentido. Devolva o cartaz para ele. O negócio dele está falindo, pelo amor de Deus.

Arthur: Por que eu ficaria com o cartaz?

Hoyt: Sei lá! Por que as pessoas fazem as coisas? Se você não devolver o cartaz, eu vou descontar do seu salário. Está claro? Ouça, eu estou tentando te ajudar, tá? E vou te dizer outra coisa. Os outros caras não se sentem à vontade perto de você porque acham que você é estranho, tá legal? E eu não posso permitir essa situação (Phillips, 2019).

Após o espancamento, Arthur recebe de Randall, colega de trabalho de intenções duvidosas, arma de fogo que, sem nenhum senso, leva consigo e deixa cair enquanto se apresenta em um hospital infantil. A arma que lhe renderia sua demissão seria a mesma utilizada parar fazer suas primeiras vítimas.

Arthur: Hoyt, por favor, eu amo este trabalho. infantil.

Hoyt: Arthur, quero saber por que você levou uma arma para um hospital

Arthur: É só um adereço. Faz parte do meu show agora.

Hoyt: Isso é mentira. Mentira. Que palhaço carrega uma arma? Randall me contou que você tentou comprar uma 38 com ele na semana passada. Você é pirado, Arthur. E mentiroso. Está despedido (Phillips, 2019)!

A narrativa nos conduz ao turning point. Até aí, Arthur Fleck não é um monstro, mas um homem comum, com seus problemas. Toma seus remédios, tem um emprego e uma mãe raquítica e doente para cuidar. Escreve suas piadas, faz planos e sonha: quer ser um famoso comediante de stand-up. Na fria e suja Gotham, representa só mais uma daquelas vidas miseráveis, marginalizadas por uma sociedade de classes marcada por conflitos e violência. A partir da virada que ocorreria no metrô, no entanto, iniciase a escalada de violência. A personagem migra da posição de vítima à de algoz. De oprimido a opressor. De Arthur Fleck a Coringa.

A bordo do metrô, vestido de palhaço e assolado por outra crise de riso incontido, Arthur presencia três rapazes, funcionários da Wayne Investments, importunarem uma jovem. Os mesmos rapazes, decidem espancá-lo ("qual é a graça, idiota?"). Segue-se cena de "ultraviolência" no melhor estilo Laranja Mecânica, enquanto o líder dos rapazes entoa Send in the Clowns. Dessa vez, no entanto, Arthur revida: com a mesma arma que lhe fez perder o emprego, mata o primeiro, depois o segundo e, por fim, descarrega todas as balas restantes no terceiro, durante tentativa frustrada de fuga. Após, esconde-se em um banheiro... dança! Um misto de dança e tai-chi-chuan. A imagem eterniza o nascimento do mais icônico vilão das histórias de super-heróis. Contemplamos, enfim, o Coringa. 
Testemunhas relatam ter visto um homem vestido de palhaço fugir da cena do crime. Thomas Wayne, bilionário dono da Wayne Enterprises e candidato a prefeito de Gotham, pai de Bruce Wayne (e também de Arthur Fleck?), concede entrevista em que lamenta a morte de seus empregados. Em sua fala pública, chama os pobres de palhaços e os repreende pelo ódio que nutrem contra os ricos:

Thomas Wayne: Parece que há uma onda de aversão aos ricos na cidade. É quase como se os moradores menos afortunados apoiassem o assassino. Sim, é uma pena. Também por isso cogito me candidatar a prefeito. Gotham perdeu o rumo.

Repórter: E sobre a declaração da testemunha de que o assassino usava uma máscara de palhaço?

Thomas Wayne: Bom, para mim faz todo sentido. Que covarde teria tanto sangue frio? Alguém escondido atrás de uma máscara. Alguém que tem inveja daqueles que têm mais sorte do que ele. No entanto, tem medo de mostrar a cara. E até esse tipo de gente mudar para melhor, aqueles dentre nós que foram bem-sucedidos na vida sempre verão aqueles que não foram como meros palhaços (Phillips, 2019).

A narrativa nos apresenta a relação romântica de Arthur com a bela vizinha Sophie. Em seguida nos deparamos com apresentação exitosa da personagem em show stand up comedy, e com outra revelação: Arthur descobre ser filho de Thomas Wayne. O enredo nos encaminha para o desfecho. Arthur recebe convite para ser entrevistado no "show de Murray" - programa de TV apresentado por seu ídolo - e a narrativa nos mostra como a população passa a usar máscaras de palhaço, em adoração ao assassino do metrô, representado como herói de Gotham (delírios de grandeza de um psicótico bipolar em fase maníaca?). "Eu acho que o cara que fez isso é um herói. Três canalhas a menos em Gotham City. Agora só falta um milhão", diz Sophie.

Arthur busca o suposto pai, desejando reconhecimento. Recebe, no entanto, um soco e uma versão dura de sua própria história. Descobrimos, com ele, que sua mãe, doente mental com passagem pelo asilo de Arkham, o adotara. O diálogo, provocado por Arthur, se dá no banheiro de um teatro. Começa com Thomas Wayne indagando se Arthur "quer um autógrafo ou algo assim?" e termina com mais um apelo por empatia:

Arthur: Por que diz isso? Não quero ouvir mentiras. Sei que parece estranho. Não quero causar incômodo. Por que todo mundo é rude? Por que você é rude? Não quero nada de você. Talvez um pouco de afeto, um abraço, pai! Que tal um pouco de decência? O que há com vocês? (Phillips, 2019).

Desejando confirmar o que ouviu, Arthur busca os arquivos de sua mãe no asilo Arkham. O diálogo com o balconista do asilo é desconcertante:

Arthur: Posso lhe fazer uma pergunta? Como uma pessoa vem parar aqui? Todos eles... todos que estão aqui cometeram crimes? 
Balconista: Bom, alguns cometeram. Alguns são somente loucos. Constituem um risco para si mesmos e para os outros. Alguns só não têm para onde ir. Não sabem o que fazer, entende?

Arthur: Sim, eu entendo, irmão. Às vezes, eu não sei o que fazer. Da última vez acabei descontando em umas pessoas. Eu achei que ia ficar incomodado com isso, mas não fiquei.

Balconista: Como assim?

Arthur: Eu me descontrolei e fiz uma coisa feia. Sabe como é. É muito difícil tentar ser...feliz o tempo inteiro.

Balconista: Ei, escuta, cara. Sou só assistente administrativo. Tipo balconista. Só arquivo a papelada. Não sei o que te dizer. Mas você deveria se consultar. Eles têm programas, serviço social, esse tipo de coisa.

Arthur: Ah, sim. Eles cortaram tudo.

Balconista: Aqui está. Penny Fleck. Vejamos. Diagnosticada pelo Dr. Benjamin Stoner. "A paciente sofre de psicose delirante e distúrbio de personalidade narcisista. Foi considerada culpada por pôr em risco o bem-estar do próprio filho" (Phillips, 2019).

Percebendo que tratava justamente com o filho da antiga paciente, o funcionário interrompe a leitura, mas Arthur toma os arquivos e os leva consigo. A câmera nos permite ver nos arquivos expressões como "comportamento extremamente bizarro", "abuso físico", "pedido de adoção". Um flashback nos transporta para a cena em que Penny Fleck é interrogada:

Interrogador: Você também não fez nada enquanto um de seus namorados batia repetidamente no seu filho adotivo e espancava você. Penny, seu filho foi encontrado amarrado a um radiador no seu apartamento imundo. Malnutrido, com múltiplas escoriações pelo corpo e trauma severo na cabeça.

Penny Fleck: Eu nunca ouvi ele chorar. Ele sempre foi um garotinho tão feliz (Phillips, 2019).

Surto de riso incontido. Nos arquivos, manchetes de notícias de jornais: "mãe permitiu maus-tratos ao filho adotivo", "casa do terror para uma mãe e seu filho". Arthur volta para casa imerso em ideação suicida. Invade o apartamento da vizinha. Descobrimos, então, que a relação dos dois era imaginária, fruto de alucinações: ela praticamente não sabe quem ele é. Quando retorna ao seu próprio apartamento, não sabemos com clareza se fez algo a Sophie ou a sua filha. Outro surto de risos. Sirenes de viaturas policiais.

Indignado, Arthur vai até o hospital para confrontar a mãe. Revela já conhecer a verdade sobre seu passado e, sem lhe dar tempo para resposta, a sufoca com o travesseiro até a morte: 
Arthur: Oi, Penny. Penny Fleck. Eu sempre odiei esse nome. Lembra como você dizia que minha risada era um distúrbio? Que tinha algo de errado comigo? Não tem. Eu sou assim mesmo. Feliz. Feliz. Eu não fui feliz um minuto sequer em toda a minha vida desgraçada. Sabe o que é engraçado? Sabe o que realmente me faz rir? Eu achava que minha vida era uma tragédia. Mas agora eu entendo que é uma puta comédia (Phillips, 2019).

Pinta o cabelo de verde e passa a ensaiar para sua apresentação no programa de Murray, onde, descobrimos, pretende cometer suicídio ao vivo. Enquanto se prepara para a entrevista, recebe a visita de dois antigos colegas de trabalho, Randall e Gary (anão), que dizem querer se solidarizar pela morte de sua mãe. Randall demonstra receio de que algo seja dito à polícia sobre a arma que dera a Arthur. $\mathrm{O}$ Coringa mata-o, de forma violenta, e, em uma das cenas mais tensas do filme, poupa Gary ("Está tudo bem Gary. Você pode ir. Eu não vou machucar você"). Quando o colega está saindo, Arthur lhe assusta, fingindo que iria atacá-lo. Gary se desdobra para alcançar a maçaneta da porta. Depois de muita relutância, precisa pedir ajuda para abri-la. "Merda. Desculpe. Gary, você foi o único que foi legal comigo", diz Arthur, beijando-lhe a testa e deixando-o sair.

Já caracterizado como Coringa e pronto para o espetáculo, dança pelas escadarias de seu bairro até ser perseguido por policiais. Consegue fugir misturando-se à turba de manifestantes com máscaras de palhaço, que se rebela contra a opressão das classes dominantes. Os policiais acabam linchados pelos manifestantes.

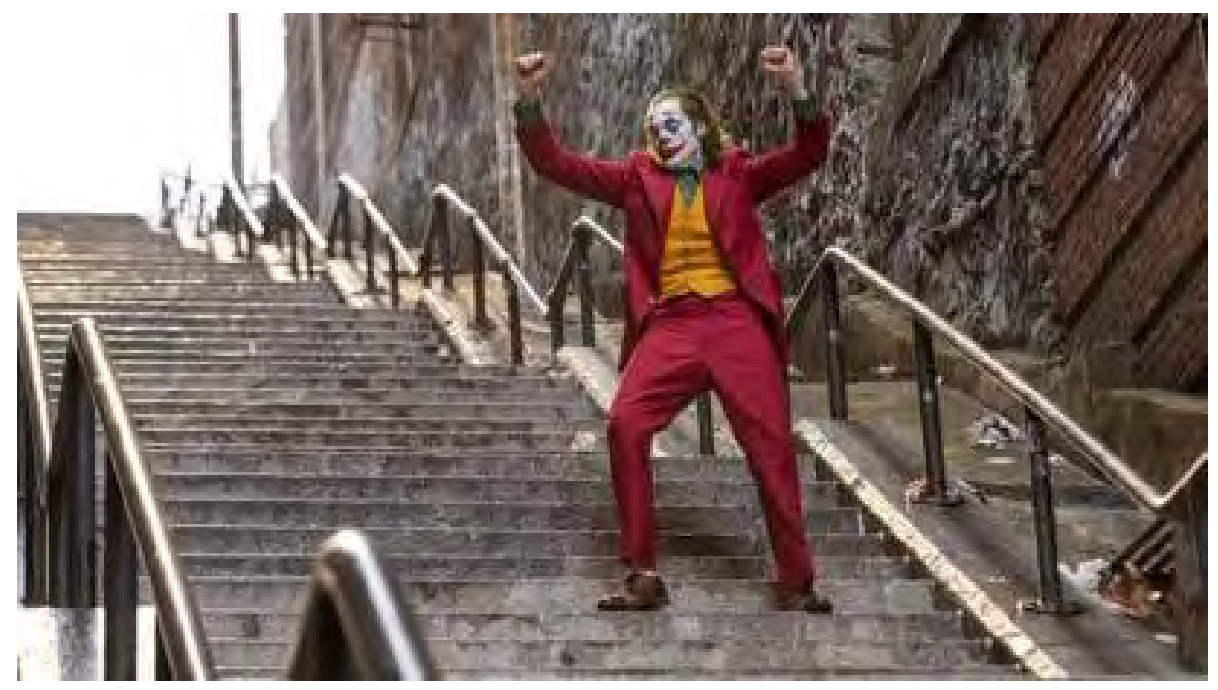

Figura 5. Atores que viveram o "Coringa".

Fonte: Phillips (2019). 


\subsection{Terceiro ato: Gotham recebe o que merece}

Ao adentrar oset de filmagem do programa, Murray pergunta por que Arthur está pintado, se faz parte dos protestos. Ele diz que não. Que não acredita em nada disso: "Eu não acredito em nada". Pede, então, para ser apresentado como Coringa. No espelho do camarim podemos ler, escrito de batom: put on a happy face.

Finalmente na entrevista, após sua entrada triunfal, é instado a contar uma piada. Abre seu caderno e entrevemos novamente a curiosa nota: "I just hope my death makes more sense cents than my life". Percebe-se que a palavra "sense" fora riscada e substituída por "cents", na frase. Segue-se uma piada desconcertante e, em meio à atmosfera nonsense, Arthur confessa, no ar, os assassinatos do metrô: "não tenho mais nada a perder. Nada mais pode me machucar. Minha vida não passa de uma comédia". E ri... Interpelado por Murray se achava engraçado o fato de ter matado três rapazes, responde questionando os binários certo/errado e engraçado/não engraçado:

Sim. E eu estou cansado de fingir que não é. Comédia é subjetiva, Murray. Não é o que dizem? Todos vocês, o sistema que sabe tanto, vocês decidem o que é certo ou errado. Assim como vocês decidem o que é engraçado ou não é (Phillips, 2019).

Murray Franklin, então, indaga se ele havia matado os jovens porque queria criar um movimento para se tornar um símbolo. Ele ensaia motivação de seu crime: "Qual é, Murray! Pareço o tipo de palhaço que começaria um movimento? Matei aqueles caras porque eles eram horríveis. Todo mundo é horrível hoje em dia. Só isso já faz qualquer um enlouquecer".

Murray devolve o argumento da loucura como fator criminógeno: "Então é isso? Você é louco? É a sua desculpa para matar três jovens?". Coringa rebate com ironia, mas também com crítica social: "Não. Eles nem sabiam cantar, para poderem se salvar. Por que todo mundo se abala por causa deles? Se fosse eu morrendo na calçada, passariam por cima. Passo todo dia por vocês, e não me notam. Mas e esses caras? Só porque Thomas Wayne chorou por eles na TV?".

O apresentador questiona, então, se ele tem um problema com Thomas Wayne. Em sua resposta, o Coringa nos alerta sobre o egoísmo e a falta de empatia. Interpela o espectador a desafiar os estigmas e subverter o binômio herói/vilão, nos colocando em seu lugar:

Sim, eu tenho. Você já viu como é lá fora, Murray? Alguma vez você sai de verdade do estúdio? Todas as pessoas só berram e gritam umas com as outras. Ninguém mais é civilizado. Ninguém pensa como é estar no lugar da outra pessoa. Acha que homens como Thomas Wayne se perguntam como é ser alguém como eu? Ser alguém senão eles mesmos? Não se perguntam. Eles acham que vamos ficar quietinhos e aguentar tudo como bons meninos! Sem reagir, sem perder o controle (Phillips, 2019)! 
Murray Franklin encarna, então, o discurso do livre-arbítrio por trás da "delinquência" e menospreza supostas motivações respaldadas pela ciência: "Você terminou? Digo, é muita autopiedade, Arthur. Está inventando desculpas por ter matado aqueles jovens. Nem todo mundo, eu te garanto, nem todo mundo é horrível". Ao que o Coringa responde: "Você é horrível. Mostrando meu vídeo, convidando-me para o programa. Você só queria debochar de mim. Você é igualzinho a todos eles". Oferece, então, uma "piada" final, que é contada a contragosto do apresentador. Por meio dela, contrapõe o argumento de Murray com argumento que interpela o repertório das criminologias (biocriminologias, sociologia criminal e suas traduções pelos advogados): "Que tal uma outra piada? O que você recebe quando cruza um solitário doente mental com uma sociedade que o abandona e o trata que nem lixo? Vou te dizer! Você recebe o que merece"!

O Coringa atira em Murray Franklin. É preso, mas acaba sendo libertado pelos manifestantes, que consomem, furiosos, a cidade de Gotham. Ao mesmo tempo em que Bruce presencia os pais sendo assassinados na saída de um cinema (o assassino atira dizendo a Thomas Wayne: "você recebe o que você merece"), uma multidão de homens e mulheres mascarados rodeia o Coringa e grita seu nome. Arthur desenha no rosto um sorriso com seu próprio sangue. O palhaço do crime alcança o sucesso almejado e torna-se símbolo de resistência das classes oprimidas. Seu oposto binário, o homem-morcego, vê nascer o desejo de vingança.

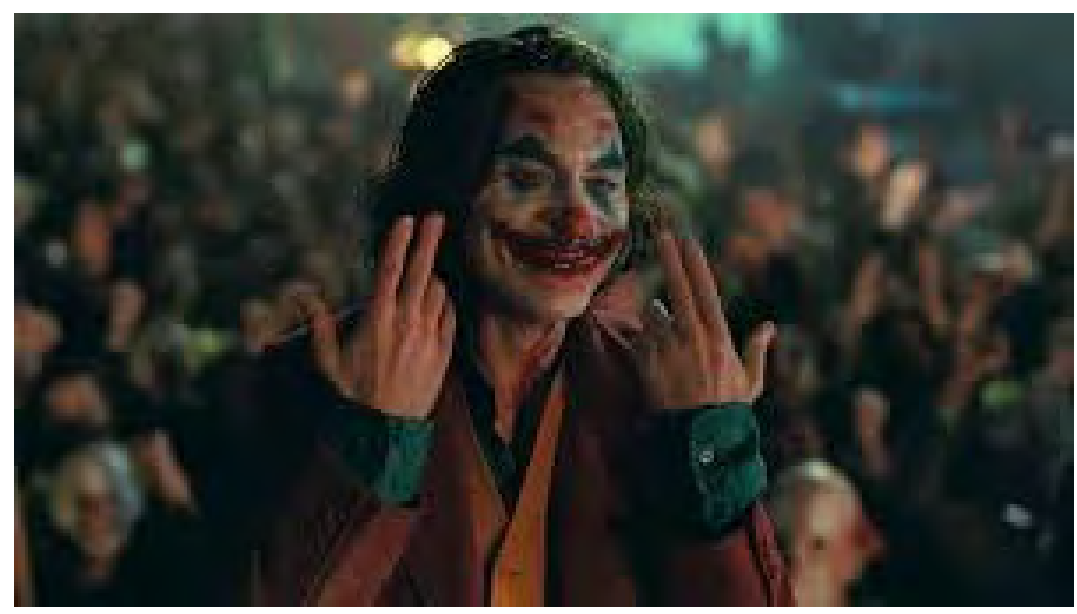

Figura 6. Atores que viveram o "Coringa"

Fonte: Phillips (2019)

A direção nos conduz a uma sessão de Arthur com outra assistente social, no asilo de Arkham. Após crise de riso incontido, a assistente questiona: 
Assistente Social: O que é tão engraçado?

Arthur: Eu estava pensando em uma piada.

Assistente Social: Você quer contar para mim?

Arthur: Você não entenderia (Phillips, 2019).

O filme transporta o espectador para a imagem do pequeno Bruce Wayne diante dos cadáveres dos pais. A piada seria Batman, o herói milionário movido por vingança que deveria ser seu oposto binário? O final transcorre ao som de música. Arthur caminha pelo corredor do asilo, deixando pegadas de sangue (provavelmente da assistente social). Dança e foge dos funcionários da instituição, que lhe perseguem.

O enredo nos direciona para um universo incômodo que desafia o nosso imaginário sobre heróis e vilões. Reminiscências da memória social de um campo específico do gênero literário que é transportado para o cinema. De outro lado, a narrativa traz consigo extenso repertório de teorias que buscam dar inteligibilidade às ações do herói/vilão. É esse o desafio que enfrentamos em seguida.

\section{MEMÓRIA SOCIAL E SEMÂNTICAS CRIMINOLÓGICAS. CRIMINOLOGIAS DE MÉDICOS, ADVOGADOS E SOCIÓLOGOS}

A trajetória do Coringa interpela a história do pensamento criminológico e a busca por explicações racionais que apresentem evidências para explicar o comportamento que se desvia das regras estabelecidas. Desde o século XIX, com a emergência da ciência moderna, diferenciam-se âmbitos específicos do conhecimento que indagam sobre o comportamento criminoso. A complexidade das respostas varia ao longo dos anos. A lente sistêmica aponta para a concorrência de distintos subsistemas sociais que pretendem explicar o desvio e suas formas de controle.

Na proposta sistêmica, a ciência é descrita como subsistema social autopoiético codificado (verdadeiro/falso), cujas operações são suplementadas pela programação (teorias e métodos). Assim operaa ciência, pois deve fazer uso de programas adicionais em relação aos conhecimentos aos quais deve ser atribuído o valor verdade (relação de complementação). Dessa forma, os programas podem ser alterados por operações internas (os códigos não). No fechamento recursivo do sistema há binarização dos programas a partir de métodos e teorias. Em outras palavras, as decisões corretas na comunicação científica são metodológicas ou teóricas (Luhmann, 1996, p. 288-290).

As teorias constroem (não há ciência sem teoria), por meio da linguagem, a forma como as argumentações podem ser comunicadas ou reformuladas. Desempenham papel importante, pois ensejam interdependências abstratas internas, o que permite a continuidade da comunicação científica, e operacionalizam as condições para sua auto substituição. Os métodos buscam orientar a decisão (entre verdade e falso) a partir 
de um problema concreto (diferente das teorias) (Luhmann, 1996, p. 291-298)6 . O surgimento das disciplinas associa-se à forma como são equacionados os problemas que surgem da combinação entre redundância (possibilidade de autoconstrução) e variação (exposição ao objeto). As relações de prestação das disciplinas em relação ao entorno são assimétricas. Algumas acessam com facilidade, pois suas construções teóricas encontram ressonância direta em sistemas sociais específicos (ex. da pesquisa biológica e o sistema saúde) (Luhmann, 1996, pp. 320-322).

\subsection{Criminologias de médicos e advogados}

O século XIX marca a diferenciação das disciplinas que colocam em questão o livre arbítrio, argumento compartilhado por juristas da época (criminologias dos advogados), e constroem parâmetros explicativos para o ato desviado. A obsessão etiológica produz as bases das disputas sobre as causas do comportamento criminoso. A definição do corpo do criminoso como objeto de pesquisa (subsistema médico-criminológico/ antropologia criminal), a ser submetido a metodologia própria (programa científico positivista) para identificação das causas do crime (disciplina etiológica) diferencia-se do argumento de fundo metafísico e religioso, ainda presente na Escola Clássica: o crime como pecado e o livre arbítrio como explicação para o comportamento criminoso (Carrara, 1977; Romagnosi, 1956). Diferencia-se, por outro lado, das teorias frenológicas, e constrói a sua identidade a partir de leituras físico-antropológicas marcadas por elementos racistas, por meio de programas (teoria e metodologias) mais complexos ${ }^{8}$. A Scuola Positiva notabiliza-se em seu impulso inicial com o "Homem delinquente" (Lombroso, 1902) as matrizes biológicas para explicação do comportamento anormal. Modelos explicativos centrados em explicações ambientes (sociológicas) atenuaram a centralidade do corpo como elemento explicativo do comportamento criminoso e produziram as versões multifatoriais, bem representadas no texto "Crime: suas causas e remédios" (Lombroso, 1902) (Garofalo, 1908; Lombroso, 2001; Ferri, 2006; Quetelet, 1993, pp. 32-46)9.

6 A possibilidade de conexão (enlace) da ciência é potencializada pela publicação (Luhmann, 1996, p. 309).

7 A diferenciação da ciência em disciplinas marca o surgimento de paradigmas ou de teorias e escolas em concorrência (Luhmann, 1996, p. 324-325). Em texto anterior sustentamos que existem subsistemas científicos concorrentes que comunicam sobre o crime, o direito penal, a política e o controle (Machado, 2012, p. 77-79). Ao mapear as comunicações sobre o crime e o direito penal, bem como a tradução das "mensagens criminológicas" nos diversos sistemas sociais abrem-se horizontes para a reflexão e (re) construção de referenciais (mapas) cognitivos na área penal (Teubner e Paterson, 1998, p. 451-453).

8 Um trecho ilustra bem o esforço de rompimento com a metafísica da Escola Clássica: "(...) seria preciso deixar de lado todas as teorias filosóficas e estudar, e suma, mais que o crime, os criminosos" (Lombroso, 2001, p. 21). Conferir também crítica à Escola Clássica e ao conceito de livre arbítrio (Ferri, 2006, p. 13).

9 A descrição de aspectos gerais do positivismo criminológico pode sugerir sistema estático, com estruturas fossilizadas e indiferente aos processos evolutivos (recursividade) e à própria reconstrução semântica das operações internas (reflexividade). A versão francesa do positivismo sugere uma preponderância do meio na explicação do comportamento delituoso (Lacassagne, 1890). O viés sociológico e o esforço em traduzir a linguagem médica aos códigos do direito sugerem processos de autodescrição e distinção em relação ao entorno segundo a racionalidade própria da semântica criminológica positivista (Ferri, 2006; Garofalo, 1908). 
As críticas ao livre arbítrio também impactaram as "criminologias dos advogados", como sugerem o modelo integrado das ciências criminais, de Liszt, ou a Terza Escola, de Alimena, Ippalomeni e Carnevale. Em comum, o argumento racional da ciência deveria ser levado em conta nas descrições da dogmática penal e nas operações do sistema de justiça criminal. De outro lado, por influência do positivismo jurídico, também floresceram propostas que reivindicaram uma ciência pura, estritamente técnicojurídica, livre das chamadas ciências auxiliares (sociologia, criminologia, antropologia). Os debates sobre a liberdade e o determinismo impactaram as legislações no transcorrer do século XX. Os arranjos institucionais, como exemplo o código penal de 1940 e reforma penal de 1984, ao tratar da imputabilidade, definiram protocolos para aferir imputabilidade (laudos), acoplados ao saber médico, a fim de definir a aplicação das penas ou medidas de segurança (Machado e Messere, 2019).

Ao longo do século XX, as teorias e metodologias iniciadas pela Scuola Positiva passaram por importantes mudanças (evolução no sentido sistêmico). As variações regionais das técnicas lombrosianas sugerem que fatores raciais e aspectos corporais foram incorporados nas argumentações teóricas do que se estabilizou como semânticas biocriminológicas contemporâneas ${ }^{10}$. Algumas destas disciplinas revelam mudança importante do ponto de vista metodológico (alteram os programas e não a codificação). Do corpo visível como sinal (estigma) de atavismos que antecipam o comportamento criminoso à sofisticação das análises biomédicas (genética criminal entre outras) da unidade corpórea infinitesimal a ser mapeada por novas tecnologias - tomografias computadorizadas e ressonâncias magnéticas -, que permitem acessar partes invisíveis do corpo humano e o "diagnóstico" de disfunções potencialmente associadas ao comportamento criminoso (Walby e Carrier, 2010, p. 275).

A diferenciação funcional das ciências psi levou a novas distinções na reinscrição do objeto a partir de programas (técnicas) próprios (Eysenck, 2003, p. 91-105). A representação do corpo aparece, assim, nas novas versões do positivismo criminológico, nas categorias sofisticadas que descrevem processos biológicos, sócio biológicos e psíquicos. Não desaparece a criminologia positivista; ela é reinventada a partir de novos programas e discursos que continuam a comunicar sobre o crime (dado indiscutido) e sobre o criminoso (Eysenck, 2003; Jalava, 2006; Sarnoff, Gabrielli e Hutchings, 1993; Simon, 1998; Walby e Carrier, 2010). Por meio de programas teóricos e metodológicos, incorpora também novos discursos no seu repertório científico. Ao invés da relação causal direta, a criminalidade congênita seria deflagrada pelo meio (Walby e Carrier, 2010, p. 276). Persiste o vínculo da nova mensagem com a remanescente narrativa

10 Nesse sentido, são paradigmáticos os escritos de recentes de Barkley sobre a preponderância dos fatores genéticos na determinação do comportamento anti-social e as reflexões de Wright, quem associa aspectos morfológicos do cérebro do afro-americano aos índices de criminalidade entre os negros nos Estados Unidos (Walby e Carrier, 2010, p. 276). 
positivista lombrosiana: a pretensão de identificar o homem criminoso e sugerir formas de defesa social.

\subsection{Criminologias dos sociólogos}

No século XX, a nascente sociologia europeia, sob influência do programa, estabiliza mensagem distinta sobre o crime e o criminoso: a explicação não se encontra no corpo humano ${ }^{11}$. Parte da criminologia sociológica (subsistema), que ganhou terreno em solo norte-americano, diferencia-se em relação ao discurso biocriminológico. A desorganização social, abordagem que surge nas primeiras décadas do século XX, reorienta a pesquisa para o espaço urbano e propõe que o desvio ocorre em razão da heterogeneidade cultural, que debilita o controle social (Shaw e McKay, 1942). Questionar o ponto de partida da criminologia positivista não era raro nas análises dos sociólogos (distintas escolas) que pesquisavam o comportamento desviado. A crítica reporta-se não apenas às metodologias de pesquisa, enviesadas pelas fontes utilizadas, mas também pela associação do crime a patologias físico-mentais e à pobreza. O modelo explicativo da desorganização também é confrontado pela associação diferencial: o desvio decorre dos contatos diferenciais com ambientes marcados por valores distintos. Aprende-se pela proximidade, intensidade e frequência dos contatos com grupos que se orientam por valores distintos e que legitimam a prática do desvio (Sutherland, 1940, pp. 1-12).

As tradições não desapareceram e nem são sucessivas. Ao contrário, persistem em diferentes modelos explicativos. Os contatos diferenciais foram reelaborados pelas modernas teorias da aprendizagem social, particularmente em diálogo com a psicologia comportamental, e sugerem que os comportamentos são aprendidos por meio do reforço diferencial (Akers, 1977). De igual modo, as teorias da desorganização social são igualmente retomadas e redirecionadas para pesquisas contemporâneas. A nova onda da abordagem da desorganização social retoma o contexto (entorno social, no caso a vizinhança) como variável explicativa. Fatores como o status socioeconômico, a mobilidade residencial e a heterogeneidade étnico-racial tornam-se centrais na pesquisa criminológica (Kornhauser, 1978). Na contemporânea teoria da eficácia coletiva, na tradição contextual, o foco éredirecionado para as conexões entre confiança mútua, coesão social e disposição para intervir em favor do bem comum. Retoma como categoria o capital social da vizinhança, que se traduz na capacidade de exercer o controle social informal, pela definição dos problemas pelas pessoas em uma comunidade com valores comuns. Nas vizinhanças marcadas pela alta eficácia coletiva, há disposição para atuar e solucionar os problemas quando apresentados, o que supõe confiança mútua e expectativas compartilhadas (Sampson, 2012).

11 Quando uma comunicação estabelece como verdadeira uma dada informação, estabelece-se uma limitação à arbitrariedade dos mundos possíveis (Luhmann, 1996,p. 195). 
No transcorrer do século XX conformam-se novos horizontes para a pesquisa sociológica. O interacionismo simbólico, vertente tipicamente norte-americana, questiona as bases metodológicas das ciências sociais e propõe novos parâmetros para análise sociológica. Neste enfoque, com claras reminiscências weberianas (Weber, 1993) e meadianas (Mead, 1973), a ação social orienta-se pelos sentidos atribuídos. Estes, por outro lado, são ressignificados pelas interações sociais. Ao contrário dos modelos simultâneos, que buscam decifrar o catálogo de fatores que levam ao comportamento desviado, sob influência interacionista, o enfoque sequencial analisa o comportamento desviado no amplo quadro dos processos de socialização e das interações do indivíduo que atua, segundo os sentidos atribuídos aos eventos, às coisas e aos encontros sociais (Becker, 2008). O foco reorienta-se para os processos sociais que iluminam o ato de desvio. Nos últimos anos, esta tradição trouxe novas possibilidades de pesquisa sociológica, de particular interesse para o estudo dos atos de violência. O interacionismo radical propõe repensar o self moldado por ambiente não conformista, onde o outro generalizado, que remete a imagem de uma comunidade unânime e estável, é substituído pela "comunidade fantasma", uma espécie de parlamento conformado por distintas experiências internalizadas ao longo da nossa vida. Na reelaboração proposta, assumem posição central os contextos de domínio nas interações concretas. A criação dos criminosos violentos pressupõe processos de socialização violenta, o que supõe repensar os modelos explicativos das carreiras violentas estáveis e crescentes (Ceretti e Natali, 2015).

Os modelos que pretendem explicar ou compreender o desvio não resumem as abordagens sociológicas. Outro ponto relevante na análise de Becker desvela nova possibilidade de observação do desvio. O enfoque é direcionado para os processos de definição do comportamento desviado, do crime e do criminoso. Na teoria relacional, o desvio deixa de ser uma qualidade do ato, mas o resultado da interação entre o impositor da regra e aquele sobre quem o rótulo é imposto. Quem tem poder para definir o que é o desvio? Quem etiquetamos como desviado? Opera-se nova diferenciação e a reconstrução da identidade científica a partir de novas abordagens ${ }^{12}$. Diferencia-se, assim, o paradigma conhecido como Labelling Approach ou Teorias do Etiquetamento (Becker, 2008; Lemert, 1951). No final da década de 1960 e princípios da década de 1970 estabiliza-se nova semântica sociológica sobre o crime, o criminoso e o comportamento desviado (Anitua, 2005; Garland, 2001, pp. 66-67; Van Swaaningen, 1997, pp. 74-107; Young, Walton e Taylor, 2001; Baratta, 1999). Emergem novas diferenças em relação ao entorno e especialmente a distinção em relação às teorias do Etiquetamento, marcadamente na vertente instrumental (marxista) do controle penal (Larrauri, 2000, pp. 54-66 e pp. 118-142). Em uma teoria materialista do desvio, o ponto central da análise são as relações sociais de produção e estrutura classista das

12 Quando a comunicação anula uma expectativa, assinalando como falsa a sua informação, gera a pergunta sobre o que seria verdadeiro. Conferir em: Luhmann (1996. p. 195). 
sociedades capitalistas, nas quais o direito penal e o sistema penal constituem-se em dispositivos de controle social sobre as classes subalternas. Nos últimos anos, as análises intersecionais de classe, gênero e raça ampliaram o espectro de análise crítica, aberta aos diferentes arranjos do controle penal moderno (Machado e Zackseski, 2019), e abriram novos rumos e tensões do debate sobre direitos humanos, Estado e direito penal ${ }^{13}$.

O que explica a trajetória do nosso herói/vilão? É um monstro, consciente de suas atrocidades? É um homem que age movido por patologias clinicamente descritas na psiquiatria ou por outros subsistemas da biocriminologia? Preexistência de enfermidade mental a ser objeto de controle médico? A desorganização social, ambiente marcado pela exclusão social da personagem? O modelo sequencial, marcado pela forma como o Coringa experimenta a frustração e se orienta pela linguagem da violência, destruidora e expressiva? A história é longa. A descrição, parcial e incompleta, é suficiente para o nosso artigo. A narrativa fílmica nos sugere múltiplas formas de observação das criminologias no cinema. Tanto o discurso médico, patologizante, pronto ao diagnóstico do mal e da anormalidade (medicamento para o transtorno psicótico), quanto as semânticas sociológicas, focadas nos sentidos que orientam as ações do vilão (herói), mediadas pela socialização e pelas interações sociais. Ou, particularmente, a lente interacionista radical: a brutalização do personagem produz o sujeito violento. Ou ainda nas vertentes sociológicas críticas, dispostas a denunciar os usos instrumentais do controle penal e os mecanismos de rotulação do sujeito desviado, imbricados com o saber médico psiquiátrico e orientados pela defesa social. Na última parte propomos outra possibilidade: observar como a arte, no caso o cinema, produz outras narrativas sobre o desvio. Livre das amarras do binarismo científico (e do binarismo dos estereótipos dos Cartoons), o Coringa nos convida a pensar as criminologias "do" cinema. Este percurso fazemos pelas lentes da desconstrução.

\section{A DESCONSTRUÇÃO DO BINÁRIO HERÓI/VILÃO E DOS BINÁRIOS DA CIÊNCIA}

A lente sistêmica, tal qual apresentamos para descrever os pensamentos criminológicos concorrentes, aponta para discursos binários e centrados sobre a verdade. O construtivismo da proposta sugere discursos programados e concorrentes, diferenciados e articulados por códigos binários.

De fato, o modo de pensar no ocidente tem se habituado, desde Platão, a reduzir o real e analisá-lo, binariamente, a partir de relações de oposição. É assim que se costuma categorizar as discussões em torno de opostos binários (bem/mal, certo/errado, homem/mulher, branco/negro, sagrado/profano, verdadeiro/falso, espírito/

13 Conferir extensa referência ao movimento e como são articuladas as reflexões sobre os novos caminhos para a pesquisa criminológica: (Van Swaaningen, (1997, pp. 51-107 e pp. 97-207; Larrauri, 2000. pp. 67-75, Machado, 2012). As percepções geram, assim, novas comunicações sobre o crime, o criminoso e o controle. 
matéria...). Nessas análises, como esclarece Derrida (1973), um dos elementos do binário tende a ser posto em posição central, privilegiada, enquanto o outro se coloca em posição marginal. Assim, os discursos são construídos no entorno do elemento central, desprivilegiando aquele que se encontra à margem. A hegemonia do elemento central conduz à sua conversão naquilo que Derrida caracteriza como "significado transcendental". A esta "metafísica da presença", caracterizada pela universalização dos elementos centrais, dos significados transcendentais, Derrida denominou "logocentrismo". Toda a história da tradição ocidental tem sido, então, para ele, a história do logocentrismo e da metafísica da presença.

A desconstrução derridiana, enquanto técnica de leitura, desafia a inverter os sinais dos opostos binários, colocando na posição central aquilo que estava à margem e descobrindo, com isso, que tipos de discursos e interpretações podem emergir a partir do mesmo texto. É exatamente o que faz a narrativa fílmica de "Coringa": inverte o binário "herói/vilão", colocando o vilão, elemento marginalizado, em posição central. A narrativa já não é feita do locus do herói, mas daquele que nunca pôde ser objeto de empatia do público, porque a história jamais foi contada a partir de sua perspectiva.

Fred Poché propõe que a desconstrução atua em quatro dimensões: 1) identifica a construção conceitual de um dado campo teórico (religião, metafísica, ética, política) que se utiliza habitualmente de opostos binários; 2) traz à luz a ordem hierárquica do binário; 3) experimenta uma leitura que inverta ou subverta a ordem dos elementos do binário; 4) revela, por meio da inversão, que a hierarquização dos elementos do binário reflete escolhas estratégicas e ideológicas, disseminando inúmeras possibili $\sim$ dades de leitura (Poché, 2007, p 54).

O Coringa que nos oferece Todd Phillips atua em cada uma dessas dimensões: 1) identifica os pares conceituais herói/vilão, no campo das narrativas de super-heróis, e etiologia/reação social, no campo das narrativas criminológicas; 2) faz refletir sobre a ordem hierárquica que se costuma atribuir a esses elementos; 3) inverte os elementos do binário (no caso herói/vilão) ou os mistura e confunde ao ponto de não ser possível encontrar neles uma hierarquia (no caso etiologia/reação social); 4) dissemina inúmeras possibilidades de compreensão não só de seu personagem principal, o Coringa, mas da figura abstrata do criminoso, desnudando como as interpretações usuais a seu respeito estão impregnadas de escolhas estratégicas e ideológicas.

Com "Coringa" o público é instado a se colocar no lugar daquele personagem historicamente demonizado. Em tempos de "bandido bom é bandido morto", a película atinge o impensável: faz o espectador torcer pelo vilão, sentir por ele empatia, compreender suas "razões". Afinal, o que há de tão diferente entre um sujeito com traumas que se veste de morcego para agredir pessoas e um sujeito com traumas que se veste de palhaço para agredir pessoas? E se os heróis estiverem lutando por um mal disfarçado (vingança) e as máscaras dos vilões escondendo motivos nobres (re- 
sistência contra a exploração de classes)? E se o morcego e o palhaço forem irmãos, filhos de um mesmo pai (o ódio)? E se forem apenas duas crianças abandonadas, dois órfãos perdidos? O que é, afinal, o Coringa? Um criminoso psicótico, um caso a ser explicado pelas "criminologias de médicos e advogados"? Um desviado cujas ações se inserem no ambiente de uma Gotham degradada e dominada pelo vício, carente de coesão social e confiança mútua entre os seus habitantes? Um homem marcado pela socialização violenta, brutalizado, que age a partir de experiências concretas que nos ajudam a compreender sua trajetória? Alguém rotulado e moldado por uma sociedade de classes que discrimina e estigmatiza e que acabou mergulhando no papel social que lhe foi atribuído? A resposta estaria, enfim, com as "criminologias de sociólogos"?

O Coringa representa, simbolicamente, o arquétipo do "criminoso" em sua forma mais plena. Demonstra o reducionismo de se tentar, por qualquer modelo científico, explicar com categorias causais a origem de fenômenos complexos como as situações problemáticas que costumamos denominar "crimes". O que explica seus atos de violência? O fato de que o homem é livre e deve ser responsabilizado por suas escolhas? A sucessão de desencontros do personagem com seu ex-chefe, com os yuppies, com Murray, marcados pela lógica da exploração capitalista e ridicularização pela audiência? O que torna alguém um criminoso? Transtornos mentais? Desorganização social com debilidade dos mecanismos de coesão e confiança mútua na comunidade? Contatos ou reforços diferenciais que sugerem a aprendizagem social da violência? Uma infância difícil marcada pela pobreza, brutalidade e socialização em contexto marcado pelo domínio e pela ofensa moral? Tudo isso? Nada disso? O mosaico de variáveis que resultou no surgimento do Coringa retratado na película é um caleidoscópio do pensamento criminológico desconstruído: mostra que tudo e, ao mesmo tempo, nada pode ser considerado como modelo explicativo para o comportamento desviante.

\section{CONCLUSÕES}

A narrativa fílmica de "Coringa" desafia os binômios "herói/vilão", "cidadão de bem/ bandido", mas também desafia o binômio criminológico "etiologia/reação social".

Arthur Fleck claramente padece de enfermidade psíquica, filho de mãe psicótica. Sofre de delírios, alucinações, surtos de riso incontido, picos de euforia maníaca, vales de depressão profunda. Controla sua vida pela ingestão de medicamentos e, tão logo esses lhe foram negados, desventuras em série se apoderaram de sua já trágica história. Por outro lado, Fleck foi uma criança abandonada, vítima de violência, tortura e maus tratos. Levava a vida difícil das classes subalternas de Gotham. Vítima de humilhação, assédio e exploração das classes mais favorecidas, alimentava sonhos que, a cada dia, se viam despedaçados pela realidade opressora e cruel.

O Coringa de Todd Phillips éum prato cheio tanto para a "criminologia de médicos e advogados" (etiológica) quanto para a "criminologia de sociólogos" (inclusive a reação social). 
Pode ser o criminoso louco da psiquiatria, como também o criminoso símbolo de resistência, o Robin Hood da criminologia crítica. Pode ser o homem submetido ao estado de saturação social de Ferri ou o criminoso atávico de Lombroso. Pode ser o desviado em comunidades desorganizadas e marcadas pela inefetividade dos mecanismos de eficácia coletiva. Pode ser o criminoso violento do interacionismo radical, brutalizado desde a infância e que incorpora a linguagem da violência. Pode ser o etiquetado da criminologia crítica, em sociedade capitalista e desigual, rotulado como marginal que acabou por mergulhar na etiqueta que lhe foi posta e agir segundo as expectativas sociais sobre si depositadas. Pode ser um monstro ou um herói. Ou pode não ser nada disso. Pode ser simplesmente um homem comum, vivendo em um contexto comum do mundo comum em que vivem milhões de outros homens e mulheres. Alguém agindo de forma desviante, como agem milhões de outros homens e mulheres feitos da mesma matéria de que somos feitos todos nós. Este, talvez, seja o grande mérito do filme: fazer perceber que o criminoso não é o Totalmente-Outro, mas um sujeito como nós.

A narrativa desenvolvida, de forma inusitada, pelos olhos do vilão, tem potencial para produzir reflexão talvez maior do que muitos tratados de criminologia. Consegue despertar empatia e compreensão no espectador comum, distanciando-o dos lugares comuns dos discursos do populismo punitivo. O filme abre caminhos a uma cultura da compreensão e da solidariedade, em lugar da demanda por alocação de culpa e imposição de penas cruéis (Villa, 2020). Se é possível, ao espectador, humanizar o mais icônico e terrível dos vilões da ficção, há também esperança de que este mesmo espectador seja capaz de reconhecer como seres humanos os sujeitos colhidos entre populações vulneráveis que acabam criminalizados e submetidos ao trato cruel estatal, racionalizado em forma de sistema penal/prisional. Afinal, não é isso que somos todos: humanos, demasiado humanos?

A película nos desvia do catálogo programado e codificado das explicações produzidas pelos discursos (semânticas) criminológicos. Subverte ao nos conduzir por uma narrativa desconcertante que testa os limites e fronteiras das ciências. "Coringa" é o tipo de filme que cumpre papel determinante em suscitar sensibilidades e abrir terrenos à cultura dos direitos humanos, em tempos em que eles se mostram tão necessários.

\section{REFERÊNCIAS}

Akers, R. (1977). Deviant behavior: a socio learning approach. Wadswoth.

Anitua, G. (2005). Historia de los pensamientos criminológicos. Del Puerto.

Baratta, A. (1999). Criminología crítica e crítica do direito penal: Introdução à sociologia do direito penal. $2^{a}$ ed IJ. Cirino dos Santos, trad.]. Freitas Bastos.

Becker, H. (2008). Outsiders: estudos de sociologia do desvio. Zahar. 
Berninger, M., Ecke, J. y Haberkorn, G. (2010). Comics as a nexus of cultures: essays on the interplay of media, disciplines and international perspectives. McFarland \& Company, Inc., Publishers.

Carrara, F. (1977). Programa de Derecho Criminal. Temis.

Ceretti, A. e Natali, L. (2015). Cosmologías violentas. Itinerarios criminológicos. Marcial Pons.

Chambliss, J. e Svitavsky, W. (2008). From pulp hero to superhero: Culture, race and identity in american popular culturer, 1900-1940. Studies in American Culture, 30(1), 1-33.

Cornelio, E. (2004). American Animated Cartoons as Genre: Poetices and cultural dilemmas Itrabalho do curso: Alternative Poetics, M.A. in Media Studies, The University of Texas. Department of RadioTelevision-Film]. https://www.academia.edu/6834995/American_Animated_Cartoons_as_a_genre_ Poetics_and_cultural_dilemmas

Derrida, J. (1973). Gramatologia. Perspectiva.

Derrida, J. (1978). Writing and Difference. University of Chicago Press.

Derrida, J. (2005). A farmácia de Platão. Iluminuras.

Eysenck, H. (1993). Personality theory and the problem of criminality. En E. Mclaughlin, J. Muncie e G. Hughes (eds.), Criminological Perspectives: Essential Readings (pp. 91-109). Sage.

Ferri, E. (2006). Sociologia Criminal. Minelli.

Garland, D. (2001). The Culture of Control: crime and social in contemporary society. Chicago University Press.

Garofalo, R. (1908). Criminologia: Estudo sobre o delicto e a repressão penal. Livraria Clássica.

Jalava, J. (2006). The modern degenerate: nineteenth-century Degeneration Theory and Modern Psychopathy Research. Theory \& Psychology, 16(3), 416-432. https://doi.org/10.1177\%2F0959354306064286

Kornhauser, R. (1978). Social sources of delinquency: an appraisal of analytic models. University of Chicago Press.

Lacassagne, A. (1890). Prefácio. Em É. Laurent (ed.), Les habitués des prisons de Paris: étude d'anthropologie e de psychologie criminélles. G. Masson.

Larrauri, E. (2000). La Herencia de la Criminología Crítica. Siglo Veintiuno de España Editores.

Lea, J. (2002). Crime \& Modernity: Continuities in Left Realist Criminology. Sage.

Lemert, E. (1951). Social Pathology. McGraw Hill.

Lombroso, C. (2001). O homem delinquente. O Livro que Mudou o Direito Penal. Notas sobre César Lombroso e sua obra.obra. Ricardo Lenz.

Lombroso, C. (1902). El delito: sus causas y remedios. Victoriano Suárez.

Luhmann, N. (1996). La ciencia de la sociedad. Anthropos.

Luhmann, N. (1997). Sociedad y sistema: la ambición de la teoría. Paidós.

Luhmann, N. (2007). La sociedad de la sociedad. Herder.

Machado, B. A. e Messere, F. (2019). Loucura, direito penal e psiquiatria: programação jurídica entre ruídos e acoplamentos. Revista Brasileira de Ciências Criminais, 27(157), 51-84.

Machado, B. e Zackseski, C. (2019). Cinema e Criminologia: interseções teóricas e críticas. Revista Brasileira de Ciências Criminais, 27(162), 287-317. 
Matthews, R. e Young, J. (1992). Issues in Realist Criminology. Sage.

Mead, G. (1973). Espíritu, persona y sociedad: Desde el punto de vista del conductismo social. Paidós.

Mortal Kombat Fandom. (n.d.). Gotham City. Acesso em 08 de julho de 2020. https://inmortalkombat. fandom.com/es/wiki/Gotham_City

Nietzsche, F. (2006). Humano, demasiado humano. Editora Escala.

Park, R. (1976). Sugestões para investigação do comportamento humano no meio urbano. Em O. Velho (ed.), O fenômeno urbano (pp. 27-67). Zahar.

Quetelet, A. (1993). On the development of the propensity to crime. Em E. Mclaughlin, J. Muncie e G. Hughes (eds.), Criminological Perspectives: Essential Readings (pp.32-46). Sage.

Phillips, T. (2019). Joker [filme]. DC Films.

Poché, F. (2007). Penser avec Jacques Derrida: comprendre la deconstruction. Chronique Sociale.

Romagnosi, G. (1956). Génesis del derecho penal. Temis.

Sampson, R. (2012). Great American City: Chicago and the enduring neighborhood effect. University of Chicago Press.

Sarnoff, A., Gabrielli, W. e Hutchings, B. (1993). Genetic factors in the etiology of criminal behavior. Em E. Mclaughlin, J. Muncie e G. Hughes (eds.), Criminological Perspectives: Essential Readings (pp. 77-90). Sage.

Schatz, T. (1981). Hollywood Genres: Formulas, Filmmaking and the Studio System. Random House.

Shaw, C. e McKay, H. (1942). Juvenile delinquency and urban areas. University of Chicago Press.

Simon, J. (1998). Managing the monstrous: Sex offenders and the new penology. Psychology, Public Policy and Law, 4(1-2), 452-467. https://psycnet.apa.org/doiLanding?doi=10.1037\%2F1076-8971.4.1 2.452

Spencer, G. (1979). Laws of form. Penguin.

Sutherland, E. (1940). White-Collar Criminality. American Sociological Review, 5(1), 1-12. www.jstor.org/ stable/2083937

Teubner, G. e Paterson, J. (1998). Changing Maps: Empirical Legal Autopoiesis. Social \& Legal Studies, 7(4), 451-486. https://doi.org/10.1177\%2F096466399800700401

Urionaguena, I. (2015-2016). The Dark Knight Trilogy: Visions/Versions of space in Gotham City. English Studies, 2-29. https://addi.ehu.es/handle/10810/21428?locale-attribute=es

Villa, L. (2020). Hegemonia e estratégia abolicionista: o abolicionismo penal como negação da crueldade. Lumen Juris.

Walby, K. e Carrier, N. (2010). The rise of biocriminology: Capturing observable bodily economies of "criminal man". Criminology \& Criminal Justice, 10(3), 261-285. https://doi.org/10.1177\%2F1748895810370314

Weber, M. (1993). Economía y Sociedad: Esbozo de sociología comprensiva. Fondo de Cultura Económica.

Young, J., Walton, P. e Taylor, I. (2001). La nueva criminología: contribución a una teoría social de la conducta desviada. Amorrotu.

Zaffaroni, E. R. (2011). Las palabras de los muertos. Ediar.

Van Swaaningen, R. (1997). Critical Criminology: Visions from Europe. Sage. 